\title{
Technical Competencies of Medical and Health Librarians in a Library 2.0 Environment*
}

\author{
Kütüphane 2.0 Ortamında Tıp ve Sağlık Kütüphanecilerinin \\ Teknik Yeterlilikleri / Yetkinlikleri
}

Joseph M. YAP**

\begin{abstract}
This study determined the acquired knowledge, perceptions and attitudes of medical and health librarians in the Philippines on the impact of Library 2.0. The study verified the level of awareness and revealed the gaps among medical and health librarians in the use, creation and adaptation of Library 2.0 tools especially in informing, educating and empowering their users. It also recognized which technology is more common to Health Science Librarians, Library 1.0 or Library 2.0, in the time of abrupt technological changes. Furthermore, the study evaluated if the librarians have learned from the previous seminars conducted by MAHLAP (or from other library organizations) on the topic of emerging technologies and Web 2.0 through demonstration of applied skills as referred by the indicators set by technical competencies for health librarians.

The study had surveyed 43 health and medical librarians in the Luzon area. Two kinds of questionnaires were sent out. First is for the officers of the Medical and Health Librarians Association of the Philippines and second is for the medical and health librarians. The first survey will determine if they allow the researcher to use MAHLAP as its collaborator for the study. The second survey is for MAHLAP members listed in the 2009 online directory.

The research introduced the draft technical competencies prepared for the medical and health librarians in the Philippines and its importance for a national and coordinated staff development program that is geared towards the improvement of their skills and knowledge that is relevant to the current demands of the library users and services.
\end{abstract}

Keywords: Medical librarians, Library 2.0, Technical competencies

\section{Öz}

Bu çalışmada, Filipinler'deki Sağlık ve Tıp sektöründe çalışan kütüphanecilerin Kütüphane 2.0. konusunda tutumlarını, algılarını ve deneyimlerini saptamayı hedeflemiştir. Bu araştırma ile kullanıcıların bilgilendirilmesinde ve eğitilmesinde, Kütüphane 2.0 uygulamalarının kullanımı, yaratımı ve adaptasyonu konularında Sağık ve Tip kütüphanecilerinin farkındalıkları

* This paper was presented during the 4th Rizal Library International Conference, October 21-22, 2010.

** Associate Librarian; De La Salle University, Manila, Philippines (joseph.yap@dlsu.edu.ph) 
doğrulanmış ve görülen eksiklikler belirlenmiştir. Araştırmada, MAHLAP (Medical and Health Librarians Association) veya diğer kütüphaneler tarafından düzenlenen önceki seminerlerden kütüphanecilerin gelişen teknolojilerve Web 2.0. uygulamaları konularında, sağlık kütüphanecileri için belirlenen teknik yeterlilik göstergeleri ışığında, bilgi edinip edinmedikleri değerlendirilmiştir.

Araştırma kapsamında 43 Sağlık ve Tıp Kütüphanecisi örneklem olarak seçilmiştir. Çalışma kapsamında Iki farklı anket uygulanmıştır. İlk olarak Filipin Sağlık ve Tip Kütüphanecileri Derneği (Medical and Health Librarians Association) çalışanları ve daha sonra 2009 yılı MAHLAP üyesi olan Sağlık ve Tip kütüphanecileri incelenmiştir.

Araştırma sonucunda, Filipinler'deki sağlık ve tıp kütüphanecilerinin teknik yeterlilikleri/ kapasiteleri ve modern kütüphane kullanıcıları ve hizmetleri ile alakalı bilgi ve becerilerin geliştirilmesini kapsayan ulusal düzeyde personel geliştirme programının önemi üzerine bir taslak ortaya koyulmuştur.

Anahtar sözcükler: Tıp kütüphanecileri, Kütüphane 2.0, Teknik yeterlilikler

\section{Introduction}

This study was developed to gauge the current knowledge, evaluate self-acceptance and determine the attitudes of health science librarians in the realm of what we often hear as "Library 2.0" tools in the era of contemporary Filipino librarianship.

Filipinos are fond of navigating and exploring what's new around the social media platform. According to a report published by Nick Burcher (2010), The Philippines ranked $8^{\text {th }}$ globally with the highest number of Facebook users as of March 31, 2010. The Philippines have generated 11,561,740 Facebook accounts (and counting) with 1027\% increase for the past 12 months. No doubt it is the most popular social networking site around the world with USA, UK, Indonesia, Turkey and France at the top 5. But, if we rank the users according to per head of population, the Philippines ranked $72^{\text {nd }}$. It is based on the total number of population versus the actual number of Facebook users (Burcher, 2010).

These reports showed that Filipinos are eager to learn new activities, specifically playing around online tools that will basically refresh our daily routine from our busy schedules. Health science librarians, as part of the Filipino workforce, generally are advocates of new knowledge being propagated within the social structure.

This study will provide an insight on how health sciences librarians bahave towards the influence set by the modern computer age in new ways of communicating and informing patrons; and organizing and repackaging their precious physical collection and virtual objects into a more diverse method of adapting to change and leaving behind computer anxiety most specially in the entry of "Library 2.0."

Library 2.0 adapted the concept of Web 2.0. Terry Flew (2008) described what he believed to characterize the difference between Web 1.0 and Web 2.0 as a "move from 
personal websites to blogs and blog site aggregation, from publishing to participation, from web content as the outcome of large up-front investment to an ongoing and interactive process, and from content management systems to links based on tagging (folksonomy)."

In libraries, it is eminent that the shift also reflects the way they promote their services and programs. Library 2.0 borrowed the concept from Web 2.0 and follows the same philosophies (Web 2.0, 2009). Library 2.0 is the application of interactive, collaborative, and multi-media web-based technologies to library services and collections (Kwanya, 2009). The focus is on user's change and participation in the creation of content and community. Similarly, the medical and health sciences adopted the term Medicine 2.0 to keep abreast with the latest use of technology in their field.

The abrupt condition of knowing which way to go in the process of improving the services of the library puts pressure on mature Filipino health librarians because of the changing library lifestyle. It should always be considered that all kinds of profession require a standardized approach in levelling the competencies and filling-in the gaps among colleagues to continuously collect, share and promote the knowledge to the clients and stakeholders even in the midst of sudden shift.

This research investigates on the competencies and actual practices of health librarians related to emerging technologies in libraries.

\section{Objectives}

The health and medical librarians are always there to support the patron's information needs. They have transformed their repositories and programs by providing neoconventional services such as the emergence of Web 2.0 technologies. Web 2.0 technologies as translated to medical and health librarianship will have a big effect on how special libraries promote their physical services into an online environment. In turn, Library 2.0 can fully support Medicine 2.0 practice. A collaborative effort among medical librarians and medical professionals should be present to continuously provide the latest trends in online medical and health information.

The objectives of this paper are to:

1. Determine the acquired knowledge, perceptions and attitudes of medical and health librarians in the Philippines on the impact of Library 2.0.

2. Know the level of awareness and reveal any gaps among medical and health librarians in the use, creation and adaptation of Library 2.0 tools especially in informing, educating and empowering their users.

3. Recognize which technology is more common to Health Science Librarians, Library 1.0 or Library 2.0, in the time of abrupt technological changes. 
4. Evaluate if the librarians have learned from the previous seminars conducted by MAHLAP (or from other library organizations) on the topic of emerging technologies and Web 2.0 through demonstration of applied skills as referred by the indicators set by technical competencies for health librarians.

5. Create a draft national competency requirement for medical and health librarians in the Philippines needed for a coordinated staff development program.

\section{Methodology}

This study surveyed about 43 health and medical librarians in the National Capital Region, Region 3 (Central Luzon) and Region 4-A (CALABARZON). But, for the purpose of presenting data for this conference, only 32 respondents will be discussed since other raw data were not yet processed.

Two kinds of questionnaires were sent out. First is for the officers of the Medical and Health Librarians Association of the Philippines and second is for the medical and health librarians. The first survey will determine if they allow the researcher to use MAHLAP as its collaborator for the study. It allows the researcher to seek approval from the Board of Directors and if they are willing to participate in the proposed workshop for Library 2.0 competency list. The survey was a basis if how prepared were the members of the Board to participate in a workshop on technical competencies for medical and health librarians utilizing Library 2.0 tools. The results of the survey came from the remaining eight transition officers for year 2009 and it showed the following (Table I):

Table I. Pre-survey Results for MAHLAP Board of Directors

\begin{tabular}{|c|c|}
\hline Result & Remarks \\
\hline$(3 / 8) 37 \%$ & $\begin{array}{l}\text { Maintains their own Library } 2.0 \text { tool (though they were not aware that all of them are } \\
\text { actually using it) }\end{array}$ \\
\hline$(7 / 8) 87 \%$ & $\begin{array}{l}\text { Thought that health care professionals can help in disseminating and promoting Library } \\
2.0 \text { in their daily work. }\end{array}$ \\
\hline $100 \%$ & $\begin{array}{l}\text { Agreed that technical competencies are important in leveraging the knowledge and } \\
\text { attitudes of health librarians emanating in a Library } 2.0 \text { environment. }\end{array}$ \\
\hline $100 \%$ & Willing to participate in a workshop related to Library 2.0 \\
\hline
\end{tabular}

The workshop was set last June 12-14, 2010 held in Iba, Zambales (in partnership with the MAHLAP Board 2010). It has 11 participants divided into three groups. The goal of the workshop is to come-up with a draft national technical competency for medical and health librarians in the Philippines applicable for Library 2.0 environment.

The learning objectives of the workshop are the following:

a. To know the acquired knowledge, perceptions and attitudes of the officers and committee members of MAHLAP towards Library 2.0 tools and identifying the ways on how they use it. 
b. To raise awareness towards the use, creation and adaptation of Library 2.0 tools especially in informing, educating and empowering library users by defining what these tools are and in what capacity they can handle these tools.

c. To evaluate, modify, approve or reject the proposed Library 2.0 matrix to be used as a tool for evaluating the technical competencies of the medical and health librarians.

The matrix was derived from the ACRL Information Literacy Competency Standards for Higher Education. This was introduced by Murphy and Moulaison (2009) in an ALA meeting in 2006 and they call it the Social Networking Literacy competencies. It has 9 competencies to be tested and is now called social media literacy competencies (an adaptation since most of the characteristics of social networking can be useful for social media and social media can encompass social networking sites).

Below is a description list of Social Media Literacy competencies:

1. Understanding and articulating social media sites and their roles: Librarians should be familiar with a diversity of social media sites including those most relevant to their patrons. Librarians also need to be able to articulate the importance of online social media sites and their applications for libraries to peers, administrators, and patrons.

2. Creating Content: The social media literate librarian is capable of creating, contributing, and revising content in various formats including images, text, audio, video, links, and more within and beyond the presence of their library in a variety of social media sites with various tools.

This extends to creating the library presence including pages, groups, profiles, and applications using new, simple, and revised programming methods like PHP, MySQL, AJAX, CSS, J2EE, widgets, gadgets, mashups, and APIs.

3. Evaluating Information: Librarians also need to be able to assist patrons in gaining and applying these skills to evaluate information they encounter in various online social networks.

4. Applying Information Ethically and Legally: The social media literate librarian applies information in social media sites ethically and legally. They respect copyright and intellectual property of information encountered and applied in social media sites, and conscious of the unique cultural norms.

This includes applying information found in social networking sites to other media and applying information to projects within social networking sites.

5. Searching and Navigating:The social media literate librarian knows how to effectively search and browse various online social media for known and unknown contacts, and for information and resources in a variety of formats. This includes understanding the search tools available within the sites, knowledge of using outside search engines to search the sites, and an understanding of what information and fields are searchable. Skills for navigating and browsing within the sites and between a variety of individual networks and outside websites is also important. 
6. Interacting: The social media literate librarian is familiar with the diverse methods of communicating with social networking sites and is aware of and able to apply the unique cultural norms and expectations of each communication method.

Also important are the skills for interacting over the various mobile communication channels popular with some social media sites. Librarians should posses the skills for interacting with patrons in these sites via smart phone applications, mobile webpages, email, software and third party clients, and text message.

7. Teaching: The social media literate librarian is capable of teaching these skills to library patrons and peers. This includes guiding and training patrons through targeted aspects of social media sites that arise in their use as resources and tools, teaching about the use of social media sites for scholarly purposes, and teaching faculty and instructors about the role of social media sites and considerations for issues affecting their students' work.

8. Providing Services: The social media literate librarian utilizes a variety of online social media sites to provide quality library services. They evaluate social media sites and choose which are most appropriate to establish a library presence in. They are capable of building and managing the library's presence in the form of profiles or applications, developing work flows for services, marketing services, weeding spam, understanding and working with privacy levels, assessing the library's presence and services, leveraging tagging and favoriting, understanding and engaging vendor and other third party applications, and being aware of relevant security topics. It is important that librarians are familiar with the steps and etiquette for initiating and responding to friend requests in building networks.

9. Flexibility: Flexibility is the defining skill for librarians engaging people and information through social networking sites. Librarians must be able to apply the above skills to unique and novel social networking sites as they emerge and evolve. Familiarity with each of the above skills in multiple social networking sites will help librarians be flexible in applying these skills to future sites and services.

Thematrixwas divided into four levels: the novice, theexperienced, the highlyexperienced and the expert (San Buenaventura, 2004). This was adapted from Gina San Buenaventura's thesis on Developing a Competency Assessment Program for Special Librarians.

The workshop provided learning activities for the three groups and they were given ample time to discuss the competencies listed in the matrix. Each group was assigned specific Library 2.0 tools that they have to focus on.

Evaluation questions were also required to be answered by each group:

1. Do the prescribed outcomes in each level reasonable enough to encapsulate each competency objectively? If not, what are your recommendations to those you think should be present/ added/ deleted in each competency and its corresponding levels? 
2. Do you think these are the only competencies that health/medical librarians should possess/embody in a so-called Library 2.0 environment?

3. Do you think the competencies listed are worthy to be published as a national guideline/ model for professional health/medical librarians in the country?

4. What do you think will be the effect to the profession if we implement this kind of competency? Cite both negative and positive effects.

The second survey is for MAHLAP members listed in the 2009 online directory. Their questionnaire is divided into seven parts: personal profile, status of employment, related Library 2.0 seminars attended communication with users, use of Library 2.0 tools, application of Web 2.0 and testing their competencies.

A face-to-face interaction with the librarians is necessary to see whether they can comprehend well with the researcher. An on-site online validation is also necessary to check whether they are really adept with the Library 2.0 tool they are talking about if they will be required to provide an example for every answer.

\section{Presentation and Analysis of Data}

\section{MAHLAP Workshop}

The MAHLAP workshop was an interactive event wherein the competency matrix for Library 2.0 tools was discussed. Each group suggested comments and recommendation for the draft matrix. After which, advantages and disadvantages were raised by the health librarians if ever this competency matrix will be implemented after the enhancement (Table II). Moreover, everyone was happy about the competency matrix and they all approved what was written in the matrix provided that revisions have to be made for some of the level outcomes for each competency (Figure 1).

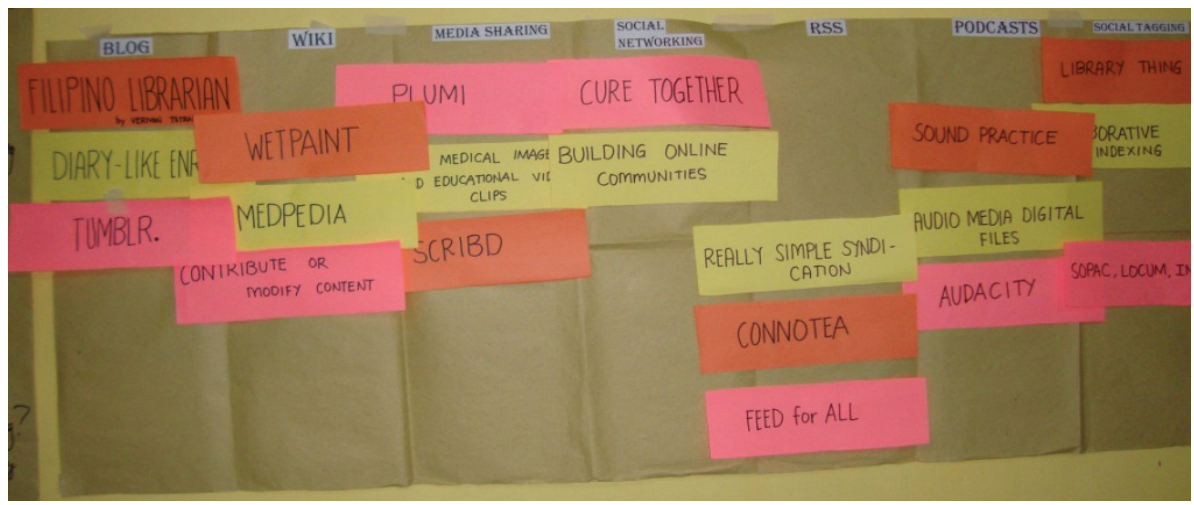

Figure 1. A Library 2.0 Activity (Provided for the Librarians) 
Table II. Responses About Advantages and Disadvantages of Testing the Competencies

\begin{tabular}{|c|c|}
\hline Advantages & Disadvantages \\
\hline $\begin{array}{l}\text { 1. Professional empowerment } \\
\text { 2. Competitive } \\
\text { 3. Uplifting the profession }\end{array}$ & $\begin{array}{l}\text { 1. The "older" librarians feels the fear of the unknown } \\
\text { 2. Additional cost for attending training, updating on current } \\
\text { trends (time, money and effort) } \\
\text { 3. Resistance to change }\end{array}$ \\
\hline
\end{tabular}

The effect of the competencies to the profession:

a. If ever this Library 2.0 list of competencies will be implemented and adapted by Medical and Health Libraries/Librarians, I think librarians working in government institutions will be highly recognized.

b. Librarians as a whole will increase its efficiency and effectiveness.

c. Web 2.0 competencies for librarians will be of great help to Human Resources Department in creating a more detailed Job description or performance standard requirements.

d. Web 2.0 technology competencies will allow librarians to train themselves and learn more skills related for their work.

\section{Competency Survey}

Based from the 32 respondents, this portion will discuss the results of the survey. Six $(18.8 \%)$ male and $26(81.35)$ female participated in the survey. It shows that the library sector is dominated by women.

Survey results shows the length of service each respondent has been working in a medical/health library. $46.9 \%$ (15) have been working for more than 4 years but less than 10 years. $31.25 \%$ (10) have been in the library industry for 11 to 20 years while $12.5 \%$ (4) have started working for 3 years or less. 9.4\% (3) have been working in this area for 21 years or more.

Only 10 (31.3\%) continued further studies and has finished their graduate courses in Library and Information Science (LIS). The remaining $68.7 \%$ is still in the process of finishing their master's degrees either in LIS or other programs and others are still reluctant to pursue higher degrees of learning.

Institution type and region of respondents is shown in Table III.

Table III. Institution Type and Region

\begin{tabular}{lcccc}
\hline \multirow{2}{*}{ Institution Type } & \multicolumn{4}{c}{ Region } \\
\cline { 2 - 5 } & NCR & III & IV-A & Total \\
\hline Hospital Library & 5 & 0 & 0 & 5 \\
Academic Health Science Library & 13 & 1 & 6 & 20 \\
Specialty Health Related Library & 5 & 0 & 0 & 5 \\
Health-related Corporate Library & 1 & 0 & 0 & 1 \\
Others: Government Library & 1 & 0 & 0 & 1 \\
\hline Total & $\mathbf{2 5}$ & $\mathbf{1}$ & $\mathbf{6}$ & $\mathbf{3 2}$ \\
\hline
\end{tabular}


As seen on the Table III, a lot of participants came from the National Capital Region representing the Academic Health Science (AHS) Libraries. Even Region III and IV-A participants came from the AHS libraries. These mean that more MAHLAP members came from this kind of institution compared to members working in Hospital Libraries or other specialty medical or health libraries. Age distribution of respondents is presented in Table IV.

Table IV. Age Distribution of Respondents

\begin{tabular}{lcc}
\hline & Frequency & Percent \\
\hline $26-35$ & 18 & 56.3 \\
$36-45$ & 6 & 18.8 \\
$46-55$ & 3 & 9.4 \\
56 and above & 5 & 15.6 \\
\hline Total & $\mathbf{3 2}$ & $\mathbf{1 0 0 . 0}$ \\
\hline
\end{tabular}

According to findings based on the Table IV, 18 (56.3\%) of respondents constitute ages 26-35. Young health science librarians are expected to implement more Library 2.0 applications in their respective libraries.

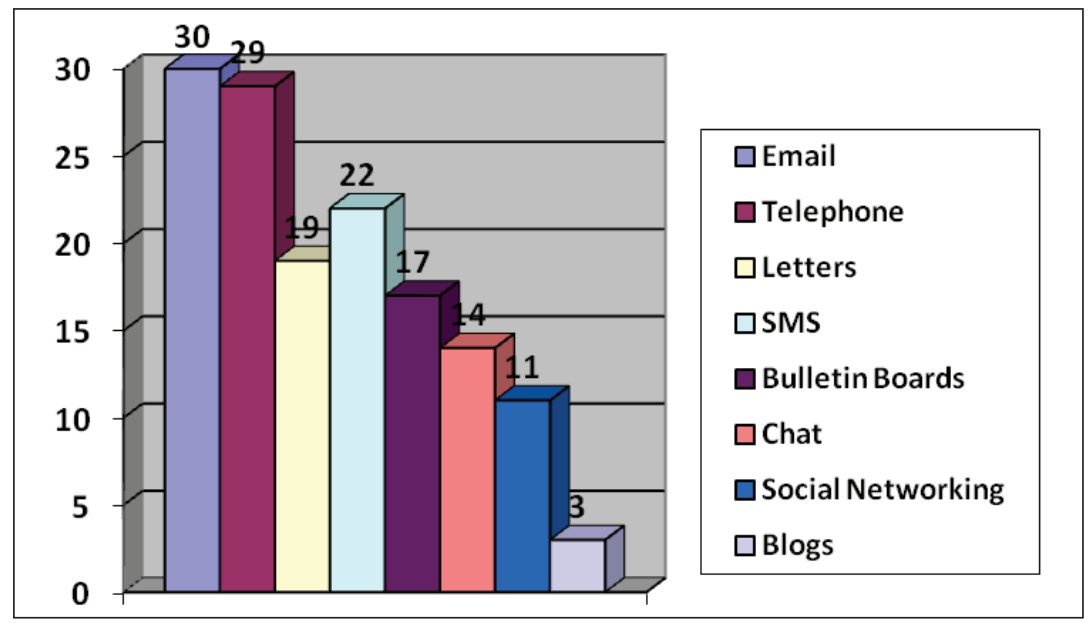

Figure 2. Communication Exchange

In Figure II, the bar graph shows that 30 out of 32 (94\%) respondents use e-mail to communicate with their users. Most of their primary email accounts are Yahoo Mail while secondary accounts are either Gmail accounts or institutional accounts. 12 of the librarians use Social Networking Service to keep-in-touch with their clients. 6 of them uses Facebook, 3 uses Friendster and the last 3 uses other social networking accounts. 
It revealed that the most accessed website is a social networking site, Facebook. Almost $22 \%$ use Facebook on their daily lives and it becomes their tool for communication and social networking.

It also showed that most of the respondents know the use of social networking sites such as Facebook, Multiply and Friendster. It was followed by Instant Messengers were most librarians use this as their virtual reference services (eg. Ask-a-Librarian). On the contrary, the use of Library Thing, World Cat or Shelfari is not the popular for Health Sciences Librarians. Podcasting and the use of RSS is also another tool they have to learn.

Discussion on:

A. Importance of Library 2.0 Technologies:

They ranked Instant Messaging, Social Networking, Media Sharing and Web-based office tools as the top four in the most important Library 2.0 tool. They believe that these four tools are powerful enough to be explored while they are online. They heavily use these tools to communicate with their fellow librarians in consultation with their colleagues and interaction with their clients while they are online.

B. Use of Library 2.0 in their Professional Life:

Since most of them sees Instant Messaging, Social Networking and Web-based office tools as their most imporant tool, it is remarkably justifiable that these three tools are being used daily by health sciences librarians in their professional life.

C. Websites Blocked:

Interestingly, Social Networking sites such as Facebook, Multiply, Friendster and even a media sharing (video) tool such as YouTube is being blocked by their network, however, they still have the capacity to use them in daily their professional lives. They are using tunneling proxy servers to connect to the websites being blocked by their institutional system. Popular proxy servers include Vtunnel and Ultrasurf.

D. Use of Library 2.0 in their Personal Life:

Even if librarians are in the library and they are online, most of them use personal Library 2.0 accounts to get connected with their users. Still, Instant Messaging, Social Networking Sites and Web-based office tools are the ones that health librarians are using in their daily personal lives.

E. Use during office hours:

This question depends on what websites were blocked by the institution. $84 \%$ said that they can access these tools during office hours while $16 \%$ cannot. Some can use Instant Messengers while others cannot. Some can access Wikipedia but not Facebook or YouTube. The answers for "no" depends if they access the websites during break time or after office hours, but still they access them inside the office. 
To answer the objectives of the study:

1. Determine the acquired knowledge, perceptions and attitudes (KPA) of medical and health librarians in the Philippines on the impact of Library 2.0 (Table V).

Table V. KPA of Librarians

\begin{tabular}{ccccccc}
\hline \multirow{2}{*}{ Tool } & \multicolumn{2}{c}{ Knowledge } & \multicolumn{2}{c}{ Perception } & \multicolumn{2}{c}{ Attitude } \\
\cline { 2 - 7 } & Yes & Rank & $\begin{array}{c}\text { Very } \\
\text { Important }\end{array}$ & Rank & $\begin{array}{c}\text { Professional } \\
\text { (Daily) }\end{array}$ & Rank \\
\hline Blog & $26(81.3 \%)$ & 3 & $11(34.3 \%)$ & 6 & $1(3 \%)$ & 8 \\
Instant Messaging & $29(90.6 \%)$ & 2 & $22(68.8 \%)$ & 1 & $23(71.9 \%)$ & 1 \\
Folksonomy & $8(25 \%)$ & 9 & $4(13 \%)$ & 9 & $1(3 \%)$ & 8 \\
$\begin{array}{c}\text { Media Sharing (slide } \\
\text { shares, photo shares, }\end{array}$ & $24(75 \%)$ & 4.5 & $18(56.2 \%)$ & 3.5 & $5(15.6 \%)$ & 4.5 \\
audio and video shares) & & & & & & $1(3 \%)$ \\
Podcasting & $12(37.5 \%)$ & 8 & $9(28.1 \%)$ & 7.5 & 8 \\
RSS & $14(43.8 \%)$ & 7 & $9(28.1 \%)$ & 7.5 & $2(6 \%)$ & 6 \\
Social Networking & $30(93.8 \%)$ & 1 & $19(59.3 \%)$ & 2 & $16(50 \%)$ & 2 \\
Web-based office tools & $24(75 \%)$ & 4.5 & $18(56.2 \%)$ & 3.5 & $10(31.2 \%)$ & 3 \\
Wikis & $23(71.9 \%)$ & 6 & $13(40.6 \%)$ & 5 & $5(15.6 \%)$ & 4.5 \\
\hline
\end{tabular}

We can say that health sciences librarians know the use of social networking (93.8\%) and they believe that it is the second important Library 2.0 tool after Instant Messaging and that most of them are using this tool on their daily professional life.

2. Know the level of awareness and reveal any gaps among medical and health librarians in the use, creation and adaptation of Library 2.0 tools especially in informing, educating and empowering their users.

Using the data on blocked sites, Friendster, Facebook, YouTube and Multiply are all social networking sites being blocked by the network/systems administrator of the institution. They were blocked because of so many reasons. Therefore, the library can't provide any services using these tools. But, the librarian should have the confidence and the negotiation power to lobby for the importance of this social media to the students and the faculty. The institution itself should advocate for alternative ways to learn on-campus and off-campus. Access to this social media sites should not be restricted because of the educational content it contributes to the academic society.

The data presented in Table VI shows the number of institutions blocked versus the number of librarians with internet access at home. 
Table VI. Blocked Sites in the Office Versus Internet Access at Home

\begin{tabular}{cc}
\hline Blocked Institutions* & Librarians with Internet Access at Home* \\
\hline 22 & 22 \\
*using Friendster as basis for blocking & ${ }^{*}$ may be DSL, wireless or broadband \\
\hline
\end{tabular}

This shows that librarians can still create an account at home and be connected with the users even after office hours. Meaning, librarians should have their own initiative to stay connected with their users.

3. Recognize which technology is more common to Health Science Librarians, Library 1.0 or Library 2.0, in the time of abrupt technological changes (Table VII).

Table VII. Library 1.0 Versus Library 2.0

\begin{tabular}{cccc}
\hline \multicolumn{2}{c}{ Library $\mathbf{1 . 0}$} & \multicolumn{2}{c}{ Library $\mathbf{2 . 0}$} \\
\hline Email & $93.8 \%$ & SMS & $69 \%$ \\
Telephone & $90.6 \%$ & Chat/IM & $44 \%$ \\
Letters & $59 \%$ & Social Networking & $34 \%$ \\
Bulletin Boards & $53 \%$ & Blogs & $9 \%$ \\
\hline Mean & $\mathbf{7 4 . 1 \%}$ & Mean & $\mathbf{3 9 \%}$ \\
\hline
\end{tabular}

Table VII shows that using e-mail is the number one way of interacting with library patrons. However, based from the mean of each library technology evolution, the traditional way of interacting with the clients using telephone, letters and bulletin boards may be classified as effective ways of reaching out to the clients. On the other hand, there are librarians who feel that using e-mail, SMS, chatting and social networking sites will also enhance the delivery of information while advocating these kinds of new media.

4. Evaluate if the librarians have learned from the previous seminars conducted by MAHLAP (or from other library organizations) on the topic of emerging technologies and Web 2.0 through demonstration of applied skills as referred by the indicators set by technical competencies for health librarians.

A total of 14 different seminars/ conferences/ workshop/studies on Library 2.0 were attended by health sciences librarians sponsored by professional library organizations or institutions. Most of the seminars attended by these librarians are lecture-type and there is no hands-on training. But, the librarian should be explorative enough to learn more about the tools that were introduced to them. Refer to the table of competencies below for a detailed discussion. 
5. Create a draft national competency requirement for medical and health librarians in the Philippines needed for a coordinated staff development program.

The competency matrix is now available. It is still considered a "draft" since it has to be reviewed again by a national committee for approval. Hence, a copy is attached in this document for public review. It may be endorsed to a higher body like the Professional Regulation Commission - Board for Librarians for acceptance. A higher learning institution or an academic institution can also review the said matrix. It can be useful to benchmark the knowledge and the expertise that a medical/health librarian should have.

Competency 1: Understanding and Articulating Library 2.0 tools and Their Roles

The data on understanding and articulating Library 2.0 tools and their roles are shown in Table VIII.

Table VIII. Competency 1

\begin{tabular}{lcc}
\hline Level & Frequency & Percent \\
\hline Below Novice & 1 & 3.1 \\
Novice & 15 & 46.9 \\
Experienced & 13 & 40.6 \\
Expert & 1 & 3.1 \\
Not Included & 2 & 6.3 \\
\hline Total & $\mathbf{3 2}$ & $\mathbf{1 0 0 . 0}$ \\
\hline
\end{tabular}

$46.9 \%$ of the respondents understand what Library 2.0 tools are. They can describe and explain the purpose of each tool and they can relay the value of it. As a requirement for the research, they should be able to define at least three Library 2.0 tools. Keywords are needed to test their competency. If they can say that, then they pass level 1. At least $40.6 \%$ are able to reach the experienced level wherein they are capable of enumerating existing social tools in the web based on the items they have defined on level 1 (the novice level). The matrix does not have a "below novice" level but it was identified that there are still librarians who are not aware of such Library 2.0 tool. On the contrary, one librarian reached the expert level. $S /$ he is able to provide a remarkable definition and understanding of more than six tools and is proficient in an advanced level of handling and maintaining these tools. 


\section{Competency 2: Creating Content}

The findings about creating content are presented in Table IX.

Table IX. Competency 2

\begin{tabular}{lcc}
\hline Level & Frequency & Percent \\
\hline Below Novice & 1 & 3.1 \\
Novice & 4 & 12.5 \\
Experienced & 21 & 65.6 \\
Highly Experienced & 4 & 12.5 \\
Not Included & 2 & 6.3 \\
\hline Total & $\mathbf{3 2}$ & $\mathbf{1 0 0 . 0}$ \\
\hline
\end{tabular}

Most of these librarians attended workshops/seminars related to Library 2.0.65.6\% are experienced on creating various Library 2.0 tools. $12.5 \%$ are highly experienced. That means that they have the brains and knowledge about the technical aspects of the back-end systems by becoming as the administrator or manager of any of those tools for their library service. If we use the data regarding their knowledge on the use of tools. We can say that the $65.6 \%$ experienced people only focuses on social networking sites, instant messengers, blogs and social media sharing. To illustrate, most of them are just viewers of YouTube, not creators of content. Therefore, they can't justify the need not to block the website because they don't produce academic outputs that they can upload on the website that may deem useful for academic learning of the institution. If they can justify that they view or download academic videos uploaded to the popular website, YouTube, then maybe the administrator will allow them to use YouTube. Other factors for blocked website include: low bandwidth, internet traffic, and misuse of website (for entertainment purposes of viewing/watching such as MTVs on YouTube and the like). Alternative medical video sites are also available for librarians like the Doctor's Channel, MEDTing, VideoMD and Anatomy TV.

\section{Competency 3: Evaluating Information}

The data related to evaluating information are shown in Table X.

Table X. Competency 3

\begin{tabular}{lcc}
\hline Level & Frequency & Percent \\
\hline Below Novice & 8 & 25.0 \\
Novice & 18 & 56.3 \\
Experienced & 4 & 12.5 \\
Not Included & 2 & 6.3 \\
\hline Total & $\mathbf{3 2}$ & $\mathbf{1 0 0 . 0}$ \\
\hline
\end{tabular}


More than half $(56.3 \%)$ of the librarians are still on the novice level. These librarians know any basic guidelines in evaluating online content. Only $12.5 \%$ follow an evaluation guideline particular for web content that is germane for blogs, wikis and other Library 2.0 tools. It is alarming that a quarter of the responsdents do not follow any evaluation guideline for online content. Their health information literacy skills should be refreshed.

Competency 4: Applying Information Ethically and Legally

Table XI reflects the data on applying information ethically and legally.

Table XI. Competency 4

\begin{tabular}{lcc}
\hline Level & Frequency & Percent \\
\hline Below Novice & 2 & 6.3 \\
Novice & 12 & 37.5 \\
Experienced & 9 & 28.1 \\
Highly Experienced & 4 & 12.5 \\
Expert & 3 & 9.4 \\
Not Included & 2 & 6.3 \\
\hline Total & $\mathbf{3 2}$ & $\mathbf{1 0 0 . 0}$ \\
\hline
\end{tabular}

This competency shows that more librarians respect the practice of academic honesty \& intellectual property rights in the Philippines. They conform to the Intellectual Property Code of the Philippines (RA 8293) and is aware of the Code of Ethics for Filipino librarians designed by the Professional Regulations Commission (PRC) signed last September 13, 2006. 28.1\% experienced librarians use and apply citation of any information gathered online in any social networking site to avoid plagiarism or other forms of intellectual misconduct. They are likewise familiar with APA, AMA, MLA and other existing standard citation formats for recording information used online. 9.3\% are considered experts because they consistently remind and monitor colleagues and clients about the importance of applying ethical and legal practices of getting health information in social networking sites by creating and using various media to promote and adhere to the highest principles of intellectual property and copyright. 


\section{Competency 5: Searching and Navigating}

The findings on searching and navigating are introduced in Table XII.

Table XII. Competency 5

\begin{tabular}{lcc}
\hline Level & Frequency & Percent \\
\hline Below Novice & 2 & 6.3 \\
Novice & 15 & 46.9 \\
Experienced & 13 & 40.6 \\
Not Included & 2 & 6.3 \\
\hline Total & $\mathbf{3 2}$ & $\mathbf{1 0 0 . 0}$ \\
\hline
\end{tabular}

Less than half of the librarians (40.6\%) demonstrate searching and navigation to any Web 2.0 site: wiki, videoshare, social network, search engine or blog. Only a few can understand the search tools available within the sites, knowledge of using outside search engines to search the sites, and an understanding of what information and fields are searchable.

\section{Competency 6: Interacting}

Table XIII shows the result of interacting.

Table XIII. Competency 6

\begin{tabular}{lcc}
\hline Level & Frequency & Percent \\
\hline Below Novice & 1 & 3.1 \\
Novice & 1 & 3.1 \\
Experienced & 7 & 21.9 \\
Highly Experienced & 18 & 56.3 \\
Expert & 3 & 9.4 \\
Not Included & 2 & 6.3 \\
\hline Total & $\mathbf{3 2}$ & $\mathbf{1 0 0 . 0}$ \\
\hline
\end{tabular}

$18(56.3 \%)$ are highly experienced in interacting with the users. That means, they do not only create blog or IM accounts but it also shows that they are aware of the social norms in communicating online. How to behave and respond to users. Eg. Use a language that is vernacular and understandable to all the subscribed members of the community. Experts in the field also uses available reading materials talking about good netizens. This include "The Ultimate Social Media Etiquette Handbook" by Tamar Weinberg. 


\section{Competency 7: Teaching}

The data related to teaching are presented in Table XIV.

Table XIV. Competency 7

\begin{tabular}{lcc}
\hline Level & Frequency & Percent \\
\hline Below Novice & 18 & 56.3 \\
Novice & 9 & 28.1 \\
Experienced & 1 & 3.1 \\
Highly Experienced & 2 & 6.3 \\
Not Included & 2 & 6.3 \\
\hline Total & $\mathbf{3 2}$ & $\mathbf{1 0 0 . 0}$ \\
\hline
\end{tabular}

This competency shows that even if they have gained knowledge and have seen the positive side of using and having Library 2.0 tools, they still do not promote the importance of social media to clients by using these tools professionally and applying them in the workplace to attract patrons about the library services. More than half (56.3\%) are below novice.

\section{Competency 8: Providing Services}

The findings about providing services are shown in Table XV.

Table XV. Competency 8

\begin{tabular}{lcc}
\hline Level & Frequency & Percent \\
\hline Below Novice & 25 & 78.1 \\
Novice & 4 & 12.5 \\
Expert & 1 & 3.1 \\
Not Included & 2 & 6.3 \\
\hline Total & $\mathbf{3 2}$ & $\mathbf{1 0 0 . 0}$ \\
\hline
\end{tabular}

A lot of librarians failed this competency level. A huge $78.1 \%$ does not provide any Library 2.0 service to their patrons. As suggested by the indicators of this competency, the social web literate librarian should be able to utilize a variety of online social networking sites to provide quality library services. They should be able to evaluate social network sites and choose which are most appropriate to establish a library presence in. They should be capable of building and managing the library's presence in the form of profiles or applications, developing work flows for services, marketing services, weeding spam, understanding and working with privacy levels, assessing the library's presence and services, leveraging tagging and favoriting, understanding and engaging vendor and other third party applications, and being aware of relevant security topics. It is important that librarians are familiar with the steps and etiquette for initiating and responding to friend requests in building networks. 


\section{Competency 9: Flexibility}

In table XVI, the results about flexibility are presented.

Table XVI. Competency 9

\begin{tabular}{lcc}
\hline Level & Frequency & Percent \\
\hline Below Novice & 3 & 9.4 \\
Novice & 26 & 81.3 \\
Experienced & 1 & 3.1 \\
Not Included & 2 & 6.3 \\
\hline Total & $\mathbf{3 2}$ & $\mathbf{1 0 0 . 0}$ \\
\hline
\end{tabular}

The researcher asked the librarians if they have understood the purpose of this research. They were asked if they could remember some competencies that a health librarian should have in a Library 2.0 environment. Prior to the survey and interview, the researcher explained the process of the library visit and it was clear in the questionnaire about the purpose of the survey and interview. It revealed that $81.3 \%$ novice librarians can remember and can explain what competencies they need in this Web 2.0 age. It was suggested that a flexible social web literate librarian must be able to apply the above skills to unique and novel social media sites as they emerge and evolve. Familiarity with each of the above skills in multiple social media sites will help librarians be flexible in applying these skills to future sites and services.

\section{Conclusions}

The utilization of social media in the Philippines is relatively high particularly with social networking sites and Instant Messengers. Generally, the surveyed librarians use their own social media space to send updates about themselves and not about the work they are doing. At some point, they unconsiously post status messages about the activities they have accomplished related to their work but not about the "event" itself wherein the library or librarian was involved. There is a need for the librarians to rethink about what these tools are all about and how it can fully help them in their daily task. They can be abusive with the personal use of these social media sites yet they can also exhaust the use of these social media by all means and justify their importance to satisfy not only their "gaming" and "liking" fashion in the online environment but as well perform their porfessional responsibilities and be proactive while they are online. It is understood that they value the importance of these tools so that they can communicate with their co-workers and with their respective clients but they have a hard time doing it in real existence. Their systems administrators block the popular websites they are visiting yet they find a way to access them by using other online tools such as online proxy servers. They just need to find a way to market their collection, services and facilities. 
As suggested by Murray and Moulaison, librarians who are not yet developed in the competencies listed above should be trained very extensively.

"Training for librarians for these critical skills can be based on learning outcomes derived from the above competencies. Teaching methods should emphasize active learning because proficiency with social media sites is most easily gained through active and personal engagement."

These competencies are designed to enhance the capacity of the librarians in providing quality services within and with the assistance of online social media sites. It will serve as a basis for future training and coordinated staff development program.

Finally, it is the librarians' role to disseminate and inform users about what is deemed available for them. Some libraries do not have their own library websites, and they can now use blogging sites to interact and communicate with the patrons. By doing so, they become information, digital and social media literate all at the same time. Passing these competencies do not say that they are not good librarians. They just have to learn how to negotiate with the management and practice what they have learned from the studies and workshops they have attended. They should also be initiative enough to find ways to endure restriction but to welcome change and innovation.

\section{Acknowledgement}

Thank you to Mrs. Lourdes David, Director, Rizal Library, Ateneo de Manila University for allowing me to publish the paper.

\section{References}

Burcher, N. (2010). Facebook usage statistics - March 2010 (with 12 month increase figures). Retrieved on January 22, 2009 from http://www.nickburcher.com/2010/03/facebook-usage-statisticsmarch-2010.html.

Flew, T. (2008). New media: An introduction (3rd Ed.). Melbourne: Oxford University Press.

Kwanya, T. (2009). Potential of library 2.0 model for research libraries in Kenya. Unpublished BSc thesis, University of Kwazulu Natal, KwaZulu-Natal.

Murphy, J. \& Moulaison, H. (2009). Social networking literacy competencies for librarians: Exploring considerations and engaging participation. In Association of College and Research Libraries (ACRL) 14th National Conference, Pushing the Edge: Explore, Engage, Extend. Seattle, Washington (US), Association of College and Research Libraries. (pp.328-330). Retrieved from http://eprints.rclis.org/bitstream/10760/13142/1/Social_networking_Literacy_for_librarians. pdf

San Buenaventura, G. (2004). Developing a competency assessment program for special libraries. Unpublished M.L.I.S. thesis, University of the Philippines Diliman, School of Library and Information Studies.

Web 2.0. (2009). In Wikipedia, The Free Encyclopedia. Retrieved on January 20, 2009 from http:// en.wikipedia.org/wiki/Web_2.0. 


\section{Reading List}

Agarwal, B. L. (2006). Basic statistics. New Delhi: New Age International.

Alpi, K. (2007). We are all public health. Journal of the Medical Library Association, 95(3), 229231. Retrieved on January 22, 2009 from http://www.pubmedcentral.nih.gov/articlerender. fcgi?artid=1924947.

Barsky, E. \& Cho, A. (2007). Introducing web 2.0: Social search for health librarians. Journal of Canadian Health Library Association, 28, 59-61.

Bradley, P. (2007). How to use Web 2.0 in your library. London: Facet Publishing.

Burnham, J. (2008). Review of the book Medical librarian 2.0: Use of web 2.0 technologies in reference services by M. Sandra Wood. Journal of Medical Library Association, 96(4), 387-388.

Cotter, L., Lewis, S. \& Wood G. (2008). EBLIP, Library 2.0 and Australian health librarians: Revealing the evidence. In The Beyond the Hype: Web 2.0 Symposium, Brisbane.

Davis, C. (2009). Web 2.0, Library 2.0, Library User 2.0 and Librarian 2.0: Innovative Services for Sustainable Libraries. In Computers in Libraries. November-December 2009 (pp. 16-21). Downloaded from Proquest.

Doktorko.com (2007). The global network of Filipino physicians. Retrieved on January 23, 2009 from http://doktorko.com/index.php.

Downie N. M. \& Heath, R. W. (1984). Basic statistical methods (5th ed.). New York: Harper International.

Eysenbach, G. (2008a). Medicine 2.0: Social networking, collaboration, participation, apomediation and openness. Journal of Medical Internet Research, 10(3). Retrieved January 222009 from http://www.jmir.org/2008/3/e22

Eysenbach, G. (2008b). Credibility of health information and digital media: New perspectives and implications for youth. M. J. Metzger, A. J. Flanagin (Eds.). In Digital Media, Youth, and Credibility. The John D and Catherine T MacArthur Foundation Series on Digital Media and Learning. Cambridge, MA: MIT Press. Retrieved on January 222009 from, http://www.mitpressjournals. org/doi/pdf/10.1162/dmal.9780262562324.123.

Farkas, M. (2007). Web 2.0 in libraries: Theory and practice [Powerpoint slides]. Retrieved on January 20, 2009 from Slideshare. http://www.slideshare.net/librarianmer/web-20-in-libraries-theoryand-practice.

Farkas, M. (2009). Library 2.0 in the real world [Powerpoint slides]. Retrieved January 20, 2009, from Slideshare. http://www.slideshare.net/librarianmer/library-20-in-the-real-world-presentation

Folksonomy. (2009). In Wikipedia, The Free Encyclopedia. Retrieved on January 22 2009, from http://en.wikipedia.org/wiki/Folksonomy.

Gavgani, V.Z. \& Mohan V.V. (2008). Application of web 2.0 tools in medical librarianship to support medicine 2.0. Webology, 5(1). Retrieved on January 22, 2009 from http://www.webology. ir/2008/v5n1/a53.html. 
Giesecke, J. \& McNeil, B. (1999). Core competencies and the learning organization. University of Nebraska-Lincoln. Retrieved January on 22, 2009 from http://digitalcommons.unl.edu/ libraryscience/60.

Giustini, D. (2006). How web 2.0 is changing medicine. British Medical Journal, 333, 1283-1284. Retrieved January on 22, 2009 from http://www.bmj.com/cgi/content/full/333/7582/1283.

Health 2.0. (2009). In Wikipedia. Retrieved on February 23, 2009 from http://en.wikipedia.org/ wiki/Medicine_2.0.

Highlight Health 2.0. (2007). Highlight health web directory, blog carnival Medicine 2.0, year 1 edition 10, November 14, 2007. Retrieved January on 22, 2009 from http://blog.highlighthealth.info/ medicine-20/medicine-20-10-medicine-and-the-second-generation-of-internet-basedservices.

Holmberg, K. (2009). What is Library 2.0? Journal of Documentation, 65(4), 668.

HONCode. (2009). Health on the Net Code. Retrieved January on 23, 2009 from http://www.hon.ch/ HONcode/Conduct.html.

Hustler, D. \& McIntyre, D. (Eds). (1996). Developing competent teachers : Approaches to professional competence in teacher education. London : Fulton Publishers.

King, D. L. (2007). Basic competencies of a 2.0 Librarian, take 2. Retrieved on January 22, 2009 from http://www.davidleeking.com/2007/07/11/basic-competencies-of-a-20-librarian-take-2.

Kraft, M. (2009). Libraries leveraging Facebook and Twitter. [Powerpoint slides]. Retrieved on January 22, 2009 from SlideShare http://www.slideshare.net/michellekraft/librariesleveraging-facebook-and-twitter.

Lapuz. E. B. (2008). Information literacy and Library 2.0. [Powerpoint slides]. Retrieved January on 22, 2009 from http://upslis.info/download.php?list.5.

Lemley, T. \& Burnham, J. (2009). Web 2.0 tools in medical and nursing school curricula. Journal of Medical Library Association, 97(1), 50-52. Retrieved from http://www.pubmedcentral.nih.gov/ articlerender.fcgi?artid=2605032.

Lewis, S. (2009). I work in a hospital library: That makes me a health librarian, doesn't it? Paper submitted for the $10^{\text {th }}$ International Congress on Medical Librarianship, 31 August to 4 September 2009, Brisbane, Queensland.

Library 2.0. (2009). In Wikipedia. Retrieved on February 23, 2009 from http://en.wikipedia.org/ wiki/Library_2.0

Lumabao, P. J. R. (2006). Library 2.0: A view from the third world. Retrieved January 22, 2009, from http://filipinolibrarian.blogspot.com/2006/01/library-20-view-from-third-world.html.

MAHLAP. (2008). MAHLAP Website. Retrieved on February 23, 2009 from http://www.mahlap.org.

Maness, J. M. (2006). Library 2.0 theory: Web 2.0 and its implications for libraries. Webology, 3(2). Retrieved on January 22, 2009, from www.webology.ir/2006/v3n2/a25.html.

MLA. (2007). MLA social networking survey. Retrieved on March 4, 2009 from http://www.mlanet. org/survey/snssurvey_public_charts.pdf. 
O'Reilly, T. (2005). What is web 2.0?: Design patterns and business models for the next generation of software. Retrieved on January 20, 2009 from http://www.oreillynet.com/pub/a/oreilly/tim/ news/2005/09/30/what-is-web-20.html?page=1.

Olandres, A. (2006). Is the Pinoy ready for Web 2.0? Retrieved January 22, 2009, from http://www. yugatech.com/blog/web-20/is-the-pinoy-ready-for-web-20.

Partridge, H., Thorpe, C., Edwards, S. \& Hallam, G. (2007). The practitioner's experience and conception of evidence based library and information practice: An exploratory analysis. In Proceedings 4th International Evidence Based Library and Information Practice Conference, Chapel Hill-Durham, NC, USA. Retrieved on March 4, 2009 from http://eprints.qut.edu. au/9946/1/9946.pdf.

Podcast. (2009). In Wikipedia, The Free Encyclopedia. Retrieved January on 22, 2009 from http:// en.wikipedia.org/wiki/Podcasting.

Preston, J. (2009). Professional education, development and training in a Web 2.0 environment: A case study of the UK. New Library World, 110(5/6), 265.

Reitz, J. (2007). Online dictionary for library and information science. Retrieved on January 22, 2009 from http://lu.com/odlis/odlis_c.cfm.

Rippen, H. \& Risk, A. (2009). e-Health Code of Ethics. Journal of Medical Internet Research, 2(2). Retrieved on January 23, 2009 from http://www.jmir.org/2000/2/e9.

Savel, R. H., Goldstein, E. B., Perencevich, E. N., \& Angood, P. B. (2007). The iCritical care podcast: A novel medium for critical care communication and education. Journal of the American Medical Informatics Association, 14, 94-99. Retrieved on January 22, 2009 from http://www.jamia.org/ cgi/content/abstract/14/1/94.

The Federal Acquisition Institute. (2008). GS-1102 competencies: Development to deployment: Preparing today's workforce for tomorrow's challenges. Retrieved February 23, 2009 from http:// oamp.od.nih.gov/NewsEvents/Symposium/08/Slides/FAl-1102Comp-LO.ppt.

Toral, J. (2009). More than 600,000 Filipinos log-on to Facebook daily. Retrieved January 22, 2009 from http://digitalfilipinocom.ning.com/profiles/blogs/more-than-600000-filipinos.

Webjunction. (2009). Competency index for the library field. Ohio: OCLC.

Weblogs - Medical Librarianship. (2008). Retrieved on January 22, 2009 from http://liswiki.org/wiki/ Weblogs_-_Medical_Librarianship.

Wiki. (2009). In Wikipedia, The Free Encyclopedia. Retrieved January 22, 2009 from http:// en.wikipedia.org/wiki/Wiki.

Wolf, A. (1995). Competence-based assessment. Buckingham: Open University Press.

Xiao, X., Zhang, X., Zhang, X., Song, L. \& Peng, M. (2008). Competencies in demand for library service in China: A national survey of recent graduates. Journal of Education for Library and Information Science, 49(4), 277-297. 